\title{
THE PI THAT WASN'T ROUND
}

\author{
How to square a circle.
}

\section{BY DAN ERLANSON}

CC

.0!" Amisha shouted. The other students laughed.

C James gave them a look to keep them quiet. "Very funny, Amisha. Try again."

"But I'm serious, Mr Wong - look!"

Amisha wasn't the brightest kid in fourth grade, but she was hard-working, and she certainly wasn't the class clown. James walked over to investigate. Along with everyone else, Amisha had used a compass to draw a circle on a piece of paper and then used a string and a ruler to measure its circumference and diameter. His class was celebrating March 14, Pi Day, and the students had been reading off their measurements. A ten-year-old and a piece of string can get you only so many significant figures, but Amisha was way outside the margin of error. James watched as Amisha remeasured her circle: 41.6 centimetres in circumference, 10.4 centimetres in diameter. The ratio expected for a square, not a circle.

“Try drawing another," James suggested. Amisha took a fresh piece of paper, carefully drew, and then measured her new circle: 23.1 centimetres in circumference, 7.4 centimetres in diameter. "3.1?” Amisha asked, a little uncertain. She picked up the string and turned back to her original drawing.

"Perfect!" James said. "I'll keep this other one."

After classes ended, James closely studied Amisha's drawing: just a plain sheet of paper with a circle filling up about a quarter of the page, slightly off-centre. He carefully measured it: 41.6 centimetres in circumference, 10.4 centimetres in diameter: $C / d=4.0$. Did it feel heavier than a normal sheet of paper? Was there a certain luminescence to it?

He took it down the hall to the staff room and made a photocopy. It looked identical, but James measured it again: 32.8 centimetres in circumference this time, still 10.4 centimetres in diameter: $C / d=3.15$. He scanned the drawing, saved the image, printed it and measured again: 10.4 centimetres in diameter, 32.8 centimetres in circumference. Whatever was strange about Amisha's circle, it couldn't be copied.

All evening he thought about the noncircular circle. His aborted $\mathrm{PhD}$ thesis was on a hypothetical particle that could cause spatial distortions if it interacted with ordinary matter. Could one of these 'strangelets'

have collided with Amisha's paper?

James needed someone to help him think this through. And although he dreaded reconnecting, he realized that the best person to turn to was his old adviser, Professor Myers. He waited until after dinner - and a stiff drink - before making the call. Of course Myers was still in his office.

"It's been a while I know, but I have something to show you. Something I think you'll find interesting."

There was a pause, then: "James? Gotten bored with the brats?"

"Can I come over?"

"Still remember how to find the department? Give me a call when you arrive and I'll buzz you in."

On his drive to the university James thought about the last conversation he had had with Myers. It was an early spring evening like this one, and James was clearing out his desk in the physics department. He had already told Myers about his decision to leave, and Myers had said little, but didn't hide his disappointment. As James was taking down the last of his photographs, he felt someone approach from behind.

"So what are you going to do?" Myers asked.

"I don't know; I was thinking of teaching elementary school."

"Teach!” Myers yelled. "Kids are even dumber than graduate students!" Then, in a lower voice: "You were the brightest student in your class - why do you want to throw that away?"

Because I was becoming too much like you, a grasping egotist with no interest in anything or anyone except his own reputation, James thought furiously, but he replied simply: "I've gotta go."

James had continued reading about physics in the years since. The work he had been doing remained untested and seem-

$\rightarrow$ NATURE.COM

Follow Futures on

Facebook at:

go.nature.com/mtoodm ingly untestable, and Myers sank into deeper obscurity, even among physicists, although he apparently remained as abrasive as ever. James had not been the first student to leave without graduating, and he certainly wasn't the last.

The building still had the same faint electrical odour that James remembered. Myers' office door was open as usual so he could keep track of his group. You quickly learned to arrive early or leave late - preferably both.

"So, what have you got? Need help grading?" James couldn't help smiling. "In a sense, yes. You remember the project I was working on? Calculating the crosssection of strangelets - "

"Of course I remember - damn shame you didn't keep at it."

"I didn't come here to argue about the past," James managed evenly. He showed Myers the drawing and explained his observations, then watched as his former adviser measured it again and again before getting up and shutting the door to his office.

"Do you realize what this may mean? This could be the first experimental evidence for my theories."

"Our theories," James reminded him.

"Yes of course, you'll get credit for finding this. But let me keep it for a while - I want to see if temperature or magnetic fields have an effect on the measurements."

There was something James didn't like in Myers' voice. “That's OK, I'll hold onto it for now," he said, picking up the paper.

"Wait, you don't realize how important this is!" Myers snatched at the drawing and pulled.

There was an audible rip, and the room filled with a brilliant emerald light. The paper seemed to shrivel in upon itself, becoming smaller and smaller until it disappeared altogether with a soft sizzling sound. The preternatural light vanished, and the two men were left staring at the empty space between them.

Dan Erlanson is a chemist who mostly enjoyed graduate school and is still on good terms with his PhD adviser. 